American Journal of Environmental Sciences 3 (4): 235-240, 2007

ISSN 1553-345X

(C) 2007 Science Publications

\title{
Evaluation of the Use of Rice Bran Compost for Eco-friendly Weed Control in Organic Farming Systems
}

\author{
${ }^{1,2}$ M. A. I. Khan, ${ }^{1,2}$ K. Ueno, ${ }^{2}$ S. Horimoto, ${ }^{1,2}$ F. Komai,,${ }^{1,2}$ K. Tanaka and ${ }^{1,2}$ Y. Ono \\ ${ }^{1}$ The United Graduate School of Agricultural Sciences, Kagoshima University, Kagoshima 890-0065, Japan \\ ${ }^{2}$ Field Science Center, Faculty of Agriculture, Saga University, Kuboizumi, Saga 849-0903, Japan
}

\begin{abstract}
Rice bran compost (RC) was evaluated under greenhouse and field conditions for ecofriendly weed control of vegetable crops in organic farming systems. RC was applied 7 days before spinach seed sowing, at the rate of $0 \%$ (control), $10 \%, 20 \%$ and $30 \%$ of soil $(\mathrm{v} / \mathrm{v})$ in the greenhouse and $2 \mathrm{~kg} \mathrm{~m}^{-2}$ under field conditions. RC significantly controlled the number and dry weight of weeds, and the weed control potentiality was increased by the increased application of RC in both years. The efficacy of RC in reducing weed emergence and dry weight of broadleaf species was higher than grass weeds. Among the broad leaf weeds, Lamium amplexicaule $\mathrm{L}$ was the most sensitive to RC and was drastically reduced by the increased application of RC. Under field conditions, the total number of weeds and the dry weight of weeds were also significantly reduced with the application of RC, compared with the untreated control. The growth inhibition potentiality of water soluble fractions of $\mathrm{RC}$ was also tested with seed germination and radicle elongation of test species (barley, oat, tomato and lettuce). The concentration response curves for the test species were drawn by plotting the percentage of germination against the logarithm of the concentration. Considering the $\mathrm{I}_{25}$ value (defined as $25 \%$ inhibition of control) both for seed germination and radicle elongation, it was indicated that water soluble fractions of $\mathrm{RC}$ was more effective in the suppression of dicotyledonous species (tomato and lettuce) than monocotyledonous species (barley and oat). The results of the preliminary experiment with fresh rice bran under greenhouse conditions showed that fresh bran suppressed spinach seed germination when applied as $10 \%$ rice bran in soil but RC did not show a significantly negative effect up to $20 \% \mathrm{RC}$ application, compared with the control. Moreover, RC enhanced spinach growth. Considering both the weed control potentiality and spinach growth enhancing ability of RC, the effective appplication rate of RC is between $10-20 \%$ of soil $(\mathrm{v} / \mathrm{v})$ for weed control as well as the successful growth of spinach. This research indicates that RC has the potential of being used as a natural herbicides.
\end{abstract}

Key words: Rice bran compost, seed germination test, selective inhibition, water soluble fractions, weed control.

\section{INTRODUCTION}

Farmers have been struggling with the presence of weeds in their fields since the beginning of agriculture. Weeds are considered a significant problem, especially in organic farming, because they tend to decrease crop yields and quality. Since the invention of herbicides, farmers have used these chemicals to eradicate weeds from their fields. The cost of the herbicides and the labor to apply them are lower than the cost of mechanical weed control; therefore, growers have become dependent on chemical controls. But long-term herbicide usage can have a potential negative impact on the environment. The Environmental Protection Agency
(EPA), USA has restricted the usage of several common herbicides in Florida, because of ground water contamination and negative effects on wildlife and humans ${ }^{[1]}$. According to a 1998 study by Britain's Consumers'Association, some pesticides remain on fruit and vegetables even after they have been washed $^{[2]}$. In the last decade, environmental concerns associated with pesticide use in agriculture have increased. Thus, the current trend of weed control is to find a non-chemical and eco-friendly solution to minimize perceived hazardous impacts from herbicides in agricultural production.

The aim of weed management strategies in organic farming is to maintain weed population at a manageable

Corresponding Author: $\quad$ K. Ueno, Field Science Center, Faculty of Agriculture, Saga University, Kuboizumi, Saga 8490903, Japan, Tel.: +81-952-98-2245, Fax: +81-952-98-2230 
level through a range of husbandry approaches. Weed management methods utilizing waste materials, such as bark, sawdust, crop residuces or by-products, were used in commercial crop production prior to chemical weed control, and organic mulches are often as effective as conventional herbicides. Moreover, a large number of plants possess inhibitory effects on the germination and growth of neighboring or successional plants by releasing allelopathic chemicals into the soil by the decomposition of their residues ${ }^{[3]}$.

Rice (Oryza sativa) is the most important food crop in the world, because it is the staple food of over half the world's population. Rice bran, derived from the outer layers of the caryopsis during milling, including the pericarp, seed coat, nucellus and part of the subaleurone layer of the starchy endosperm, accounts for 5 to $8 \%$ of the rough rice weight. It contains valuable components such as oil, protein, vitamins and some essential minerals as well as enzymes, microorganisms, natural toxicant constituents, harmful contaminants and adulterants ${ }^{[4]}$. Several reports have been published on rice bran allelopathy for controlling weeds in rice fields, but the research on vegetable weed control by using rice bran has not yet been investigated throughly. The use of fresh bran in upland vegetable crops sometimes creates germination inhibition, as well as growth suppression of the crop. In recent year, it has been realized that the application of composted materials to the soil is more beneficial than direct application of raw materials, because raw materials might contain phytotoxic organic materials or ammonia, which may cause phytotoxicity to vegetable crops. Additionally, water is necessary for the decomposition of rice bran for efficient control of weeds, therefore the controlling of upland vegetable weeds using rice bran presents more difficulties than lowland. Considering the above facts, the use of rice bran compost could be a usefull way for eco-friendly and non-chemical weed control in organic farming systems of upland vegetables.

The objectives of this study were to evaluate the weed control potentiality and spinach growth enhancing ability of rice bran compost, and also the growth suppression ability of the water-soluble inhibitors of rice bran compost, that might be useful for eco-friendly weed control in organic farming systems.

\section{MATERIALS AND METHODS}

The experiments were conducted consecutively for two years under greenhouse (autumn of 2004 and 2005), under field (autumn of 2005) and under laboratory conditions in the Field Science Center, Saga University, Japan ( $33^{\circ} 18^{\prime} 20^{\prime \prime} \mathrm{N}$ and $\left.130^{\circ} 20^{\prime} 12^{\prime \prime} \mathrm{E}\right)$.

Composting procedure: Rice bran compost (RC) was prepared in a $45 \mathrm{~L}$ plastic bucket (height: $49.5 \mathrm{~cm}$ and diameter: $42.7 \mathrm{~cm}$, Belc, Risu Corporation, Japan) with three replications (maintaining 3 buckets separately) and allowed to decompose for 6 months (composting started from March) in a glasshouse. The bran of 'Hinohikari' (a popular Japanese rice variety) was used in this experiment and it was collected from the Field Science Center, Saga University, Japan. The moisture content was adjusted to between 55 to $60 \%$ at the start of composting. The composting buckets were turned upside down once a week. The mature compost was kept frozen $\left(-20^{\circ} \mathrm{C}\right)$ until used for bioassay.

Greenhouse experiment: The soil of this experiment was collected from the Organic Farm of Saga University, Japan where no agrochemicals were used for the last 10 years, and contained large numbers of weed seeds naturally. The soil was air dried and sieved with $3 \mathrm{~mm}$ plastic sieve for the equal distribution of the weed seeds. RC was applied during the final bed preparation (7 days before sowing of spinach seeds) at the rate of $0 \%$ (control, only soil), $10 \%, 20 \%$ and $30 \%$ $(\mathrm{v} / \mathrm{v})$ of soil. The physio-chemical properties of the soil and RC are presented in Table 1 . The bed size was 0.24 $\mathrm{m}^{2}$. Three spinach seeds (Jiromaru, Takii Seed, Japan) hill $^{-1}$ were sown maintaining a line to line distance of $10 \mathrm{~cm}$ and plant to plant distance of $8 \mathrm{~cm}$, during the first week of October in both 2004 and 2005. After germination, one healthy plant was kept hill' ${ }^{-1}$. Weed data such as the name, number and dry weight were collected 30 days after the sowing of the spinach seed. The growth parameters of spinach were also investigated in this experiment. The leaf chlorophyll content of the spinach $\left(\mathrm{mg} 100 \mathrm{~cm}^{-2}\right)$ was calculated by substituting the SPAD reading for $\mathrm{X}$ in the standard formula $Y=0.0996 \mathrm{X}-0.152^{[5]}$. No agrochemicals were used during the experimentation. Only water was supplied when necessary. Additionally, a preliminary experiment was conducted with fresh rice bran to evaluate the effect of rice bran on the seed germination of spinach under greenhouse conditions. The other practices of this experiment were the same as the previous experiment. All the experiments were conducted in a completely randomized block design with three replications.

Field experiment: The field experiments were conducted in the autumn of 2005, at the organic farm of the Field Science Center, Saga University, Japan to test the weed control potentiality of RC compared with the of non-treated control (soil only). The field was divided into small plots with an area of $2 \times 1 \mathrm{~m}^{2}$, with three 
Am. J. Environ. Sci., 3 (4): 235-240, 2007

Table 1: Physio-chemical properties of rice bran compost (RC) and soil used in the experiment

\begin{tabular}{cccccccccccc}
\hline Sample & $\mathrm{pH}$ & $\begin{array}{c}\mathrm{EC} \\
\left(\mathrm{dS} \mathrm{cm}^{-1}\right)\end{array}$ & $\begin{array}{c}\mathrm{C} \\
(\%)\end{array}$ & $\begin{array}{c}\mathrm{T}-\mathrm{N} \\
(\%)\end{array}$ & $\begin{array}{c}\mathrm{C} / \mathrm{N} \\
\mathrm{ratio}\end{array}$ & $\begin{array}{c}\mathrm{P} \\
(\%)\end{array}$ & $\begin{array}{c}\mathrm{K} \\
(\%)\end{array}$ & $\begin{array}{c}\mathrm{Ca} \\
(\%)\end{array}$ & $\begin{array}{c}\mathrm{Mg} \\
(\%)\end{array}$ & $\begin{array}{c}\mathrm{Fe} \\
(\%)\end{array}$ & $\begin{array}{c}\mathrm{Na} \\
(\%)\end{array}$ \\
\hline $\mathrm{RC}$ & 6.1 & 10.8 & 34.4 & 4.4 & 7.9 & 0.5 & 5.0 & 0.1 & 2.3 & 0.1 \\
Soil & 6.4 & 0.2 & 3.7 & 0.4 & 9.5 & 0.01 & 0.02 & 0.1 & 0.01 & 0.0002 & 0.01 \\
\hline
\end{tabular}

replications, in a completely randomized block design. $\mathrm{RC}$ was applied during the final land preparation (7 days before sowing of spinach seed) at the rate of $2 \mathrm{~kg}$ $\mathrm{m}^{-2}$. Three spinach seeds hill'-1 were sown maintaining a line to line distance of $25 \mathrm{~cm}$ and plant to plant distance of $15 \mathrm{~cm}$ during the first week of October, 2005. Weed data, such as the total number and dry weight per $\mathrm{m}^{2}$, were collected 30 days after the sowing of the spinach seed.

Separation of the water soluble fractions of RC: A crude aqueous extract was prepared by stirring $100 \mathrm{~g}$ of oven dried $\left(60{ }^{\circ} \mathrm{C}\right.$ for $24 \mathrm{hr}$ with forced air) ground rice bran compost (RC) with $1000 \mathrm{ml}$ of distilled water for $12 \mathrm{hr}$ at $<5^{\circ} \mathrm{C}$ temperature. The mixture was then filtered through four layers of cheesecloth to remove coarse particles. The extract was filtered again through filter paper (Advantec No. 5A) using a glass funnel. The clear extract was obtained and concentrated under reduced pressure at $60^{\circ} \mathrm{C}$ and preserved at $-20^{\circ} \mathrm{C}$ until its use in the bioassay.

Seed bioassay: The presence of the phytotoxic compounds in RC was evaluated through barley (Hordeum vulgare) var. Nishinogold, JA, Japan; oat (Avena strigosa) var. Hei ootsu, Snow Brand Seed, Japan; radish (Raphanus sativus L.) var. Tokinashidaikon, Yae Seed, Japan; tomato (Lycopersicon esculentum) var. Oogata-fukuju, Takii Seed, Japan; lettuce (Lactuca sativa) var. Cisco, Takii Seed, Japan. Prior to seed bioassay, the concentrated water soluble fractions of RC was again diluted with distilled water as necessary to get the desired concentrations from 0.005 to $1.0 \%(\mathrm{w} / \mathrm{v})$. The treatment consisted of 11 test species seeds imbibed and incubated for $72 \mathrm{hr}$ at $25^{\circ} \mathrm{C}$, under completely dark conditions, in $5 \mathrm{ml}$ of either solution of the RC water soluble fraction or distilled water (control) in a covered $9 \mathrm{~cm}$ petridish on a double sheet of sterile filter paper (Advantec No. 2). The petridishes were sealed with parafilm (Parafilm ' $M$ ' Laboratory Film American National Can TM). The percentage of seed germination and radicle elongation were calculated by reference to the control treated with distilled water. The experimental design was a completely randomized design with the treatment replicated five times.
Statistical analysis: The data of this study was analyzed using SAS 6.12 version using ANOVA with Tukey`s test $(\mathrm{P}<0.05)$.

\section{RESULTS AND DISCUSSION}

Weed control potentiality of rice bran compost (RC): The overall data showed that $\mathrm{RC}$ reduced the weed biomass significantly in both years 2004 and 2005 when it was applied in the soil, and it was positively correlated with the application rate of $\mathrm{RC}$ under greenhouse conditions (Table 2 and Table 3). The results also showed that the reduction of broadleaf weeds was higher than that of grass weeds. In 2004, the application of $10 \% \mathrm{RC}$ significantly reduced the plant stand of grassy weeds compared with the untreated control. However, there was no significant difference $(\mathrm{P}<0.05)$ among the $10 \%, 20 \%$ and $30 \%$ RC applications. Again, in 2005, RC did not show any significant effect $(\mathrm{P}<0.05)$ on the suppression of grass weed stands (Table 2). In the same way, the application of $10 \% \mathrm{RC}$ significantly reduced the dry weight of grass weeds compared with the untreated control, but there was no significant difference $(\mathrm{P}<0.05)$ among the $10 \%, 20 \%$ and $30 \%$ RC applications both in 2004 and 2005 (Table 3). On the other hand, broadleaf weeds were drastically reduced (both in number and dry weight) with the application of $\mathrm{RC}$, and the reduction percentage over control was increased with the increased application of RC, both in 2004 and 2005 (Table 2 and Table 3 ). The overall data on the reduction (\%) of weed stands and dry weight relative to the control with RC, showed that the weed control potentiality of RC was selective, and it was more effective in controlling the broad leaf weeds than the grassy weeds both in 2004 and 2005. The highest number of grass and broadleaf weeds were obtained from the control treatment (untreated soil). Three broad leaf weeds such as Lamium amplexicaule L (local name: hotokenoza, family: Labia), Capsella bursapastoris Medius (local name: nazuna, family: Cruciferae) and Amaranthus sp. (local name: hiyu, family: Amarentheceae), and two grass weeds such as Digitaria ciliaris Koeler (local name: mehishiba, family: Gramineae) and Cyperus iria L. (local name: kogomegayatsuri, family: Gramineae) were found in 
Table 2: Effects of rice bran compost (RC) application on weed number under greenhouse conditions in the autumn of 2004 and 2005

\begin{tabular}{ccccc}
\hline RC application & \multicolumn{2}{c}{ Weed stand reduction ( \% of control) } \\
\cline { 2 - 5 } rate & \multicolumn{2}{c}{ Grassy weeds } & \multicolumn{3}{c}{ Broadleaf weeds } \\
\cline { 2 - 5 } (\% of soil) & 2004 & 2005 & 2004 & 2005 \\
\hline 10 & $14.0 \mathrm{a}$ & $1.5 \mathrm{a}$ & $22.6 \mathrm{a}$ & $37.3 \mathrm{a}$ \\
20 & $17.5 \mathrm{a}$ & $1.6 \mathrm{a}$ & $41.5 \mathrm{~b}$ & $79.2 \mathrm{~b}$ \\
30 & $22.8 \mathrm{a}$ & $1.7 \mathrm{a}$ & $58.5 \mathrm{c}$ & $92.5 \mathrm{c}$ \\
\hline
\end{tabular}

RC was applied volume basis (v/v) of soil. Means separated by Tukey's test. Values in the column with the same letter are not significantly different at $\mathrm{P}<0.05$.

Table 3: Effects of rice bran compost (RC) application on weed dry weight under greenhouse conditions in the autumn of 2004 and 2005

\begin{tabular}{ccccc}
\hline \multirow{2}{*}{$\begin{array}{c}\text { RC application } \\
\text { rate }\end{array}$} & \multicolumn{3}{c}{ Weed dry weight reduction (\% of control) } \\
\cline { 2 - 5 } (\% of soil) & \multicolumn{2}{c}{ Grassy weeds } & \multicolumn{2}{c}{ Broadleaf weeds } \\
\cline { 2 - 5 } & 2004 & 2005 & 2004 & 2005 \\
\hline 10 & $42.3 \mathrm{a}$ & $38.8 \mathrm{a}$ & $52.1 \mathrm{a}$ & $50.4 \mathrm{a}$ \\
20 & $42.9 \mathrm{a}$ & $39.0 \mathrm{a}$ & $70.5 \mathrm{~b}$ & $70.9 \mathrm{~b}$ \\
30 & $45.4 \mathrm{a}$ & $43.2 \mathrm{a}$ & $90.4 \mathrm{c}$ & $85.8 \mathrm{c}$ \\
\hline
\end{tabular}

RC was applied volume basis (v/v) of soil. Means separated by Tukey's test. Values in the column with the same letter are not significantly different at $\mathrm{P}<0.05$.

the control treatment. Among the broad leaf weeds, Lamium amplexicaule $\mathrm{L}$ was the most sensitive to $\mathrm{RC}$ and was significantly reduced with the increased application of RC. In 2004, the soils for the experiment were collected from the continuously cultivated area of the organic farm where weed population was comparatively low. But in 2005, the soils for the experiment were collected from the area of organic farm where no crops were grown within the year, and the soil was infested with a comparatively high amount of weed seeds. The results of this experiment are in partial agreement with the findings of Kuk et al. ${ }^{[6]}$, who found that the weed control potentiality of fresh rice bran was selective, and it was more effective on the broadleaf weeds than grass weeds. The organic mulch reduced weed growth because of the high concentration of phytotoxic substances including organic acids, ammonia, ethylene oxide, and phenolic compounds ${ }^{[7]}$. The results of this experiment make it possible to suspect that RC might contain growth inhibitors which were responsible in suppressing the weed population and biomass, and that the inhibition potentiality of RC was selective.

To determine the weed control potentiality of RC under field conditions in an organic farming system, 2 $\mathrm{kg} \mathrm{m}^{-2} \mathrm{RC}$ was applied in the soil. The total number of weeds and dry weight per $\mathrm{m}^{2}$ were significantly reduced with the application of RC, compared with the untreated control (Table 4). The results clearly showed .
Table 4: Effects of rice bran compost (RC) application on weed number and dry weight under field conditions in the organic farming system on autumn, 2005

\begin{tabular}{lll}
\hline Treatments & $\begin{array}{c}\text { No. of weeds } \\
\left(\text { No. } \mathrm{m}^{-2}\right)\end{array}$ & $\begin{array}{c}\text { Weed dry weight } \\
\left(\mathrm{g} \mathrm{m}^{-2}\right)\end{array}$ \\
\hline Control & $670 \mathrm{a}$ & $75.8 \mathrm{a}$ \\
RC & $350(-47.8) \mathrm{b}$ & $30.7(-59.5) \mathrm{b}$ \\
\hline
\end{tabular}

$\overline{\mathrm{RC}}$ was applied at the rate of $2 \mathrm{~kg} \mathrm{~m}^{-2}$. Data in parentheses indicate the percent decrease over control. Values in the column with the same letter are not significantly different at $\mathrm{P}<0.05$.

that $\mathrm{RC}$ has a strong ability to control weeds in vegetable crops in an organic farming system.

Seed germination and radicle inhibition potentiality of the water soluble fractions of RC to test species: Several recent activities suggest that growth inhibition tests of compost for seed germination rate and root elongation of higher terrestrial plants are a valuable part of ecotoxicology. The growth inhibition potentiality of the water soluble growth inhibitors of $\mathrm{RC}$ was tested with seed germination, and radicle elongation of barley, oat, tomato and lettuce (Fig. 1 and Fig. 2). The concentration response curves for the test species were drawn by plotting the percentage of germination against the logarithm of the concentration. All four test species` germination were suppressed, but by far the greater inhibition was observed in case of tomato and lettuce than barley and oat (Fig. 1). The concentrations required for $25 \%$ inhibition (defined as $\mathrm{I}_{25}$ ) were $0.18 \%$, $0.27 \%, 0.53 \%$ and $>1.0 \%$ for lettuce, tomato, oat and barley respectively, as interpolated from the response curves. The average $\mathrm{I}_{25}$ value of lettuce and tomato was smaller than barley and oat. Figure 2 shows the effect of the water soluble fraction of $\mathrm{RC}$ on radicle elongation of all four test species. The $\mathrm{I}_{25}$ values in the assay being $0.02 \%, 0.06 \%, 0.21 \%$ and $0.63 \%$ for the lettuce, tomato, oat and barley, respectively. In all bioassays, the average $I_{25}$ values of lettuce and tomato were smaller than that of barley and oat. There are some reports on the selective growth inhibition effect of compost on the test plants. The phytotoxicity of the spent litter depended both on the age of the spent litter and the plant species $^{[8]}$. The water extracts of the compost produced from active sludge and coffee residue were found to be selective in the inhibition of seed germination in some legumes ${ }^{[9]}$. The n-hexane, acetone and water soluble fractions obtained from shoot extracts of Evolvulus alsinoides were more effective on the seed germination of dicotyledonous species (cockscomb, cress and lettuce) than monocotyledonous species (crabgrass, timothy and ryegrass) ${ }^{[10]}$. 


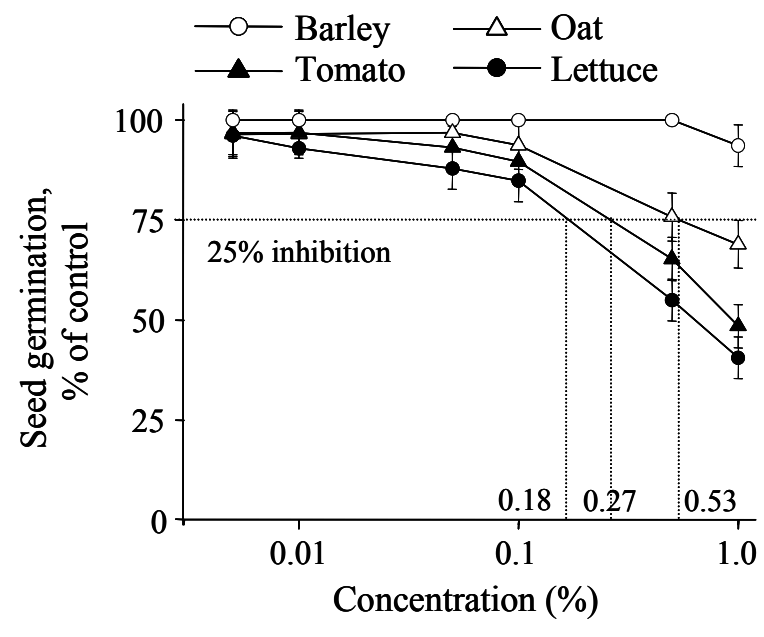

Fig. 1: Inhibitory activity of the water soluble fractions of rice bran compost (RC) on the seed germination of barley, oat, tomato and lettuce (test species). Error bars represent $\pm \mathrm{SD}$ from 5 replications. Germination rate of control was $100 \pm 0.0 \%$ for barley, $87.9 \pm$ $5.2 \%$ for oat, $97.0 \pm 5.2 \%$ for tomato and 100 $\pm 0.0 \%$ for lettuce

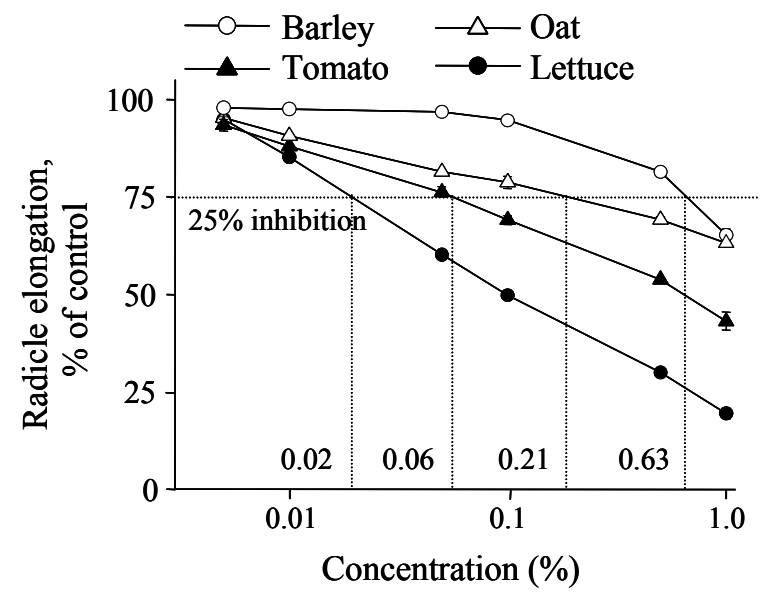

Fig. 2: Inhibitory activity of the water soluble fractions of rice bran compost (RC) on the radicle elongation of barley, oat, tomato and lettuce (test species). Error bars represent $\pm \mathrm{SD}$ from 5 replications. Radicle elongation of control was $71.7 \pm 0.2 \mathrm{~mm}$ for barley, $27.3 \pm$ $0.01 \mathrm{~mm}$ for oat, $18.6 \pm 0.2 \mathrm{~mm}$ for tomato and $24.0 \pm 0.6 \mathrm{~mm}$ for lettuce
The results of this experiment are in partial agreement with the above findings, and indicate that the $\mathrm{RC}$ water soluble fraction has a selective inhibition effect, and it was more effective in the suppression of seed germination and radicle elongation of dicotyledonous species (tomato and lettuce) than monocotyledonous species (barley and oat). This study also suggests that there is a possibility for the use of water soluble fractions of RC as an organic herbicide which can help to reduce the dependency on hazardous synthetic herbicides.

Effect of RC on spinach growth: Spinach was also tested for tolerance to RC. When used at $10 \% \mathrm{RC}$ in soil, it significantly enhanced the plant height and fresh weight of spinach compared with other treatments (Table 5). The highest plant height $(161.0 \mathrm{~mm})$, fresh weight $\left(8.55 \mathrm{~g} \mathrm{plant}^{-1}\right)$ and leaf chlorophyll content $\left(3.53 \mathrm{mg} 100 \mathrm{~cm}^{-2}\right.$ ) were obtained from $10 \% \mathrm{RC}$ applicated spinach. There was no significant difference of chlorophyll content up to $30 \% \mathrm{RC}$ application.

The results of the preliminary experiment with fresh and composted rice bran (RC) on the seed germination of spinach showed that there was no negative effect on seed germination in soil upto $20 \% \mathrm{RC}$ application, but fresh bran suppressed the seed germination when applied at $10 \%$ rice bran in soil (Fig. 3). Fresh materials might contain phytotoxic organic materials or ammonia which may cause phytotoxicity to vegetable crops ${ }^{[11]}$. The highest seed germination $(62.1 \%)$ was obtainted from both the $10 \% \mathrm{RC}$ application and control treatments. This result suggest that the application of rice bran compost to vegetable fields is better practice than the application of fresh bran. Further study is necessary to evaluate the weed control potentiality of water soluble fractions of $\mathrm{RC}$, and in screening the different vegetable crops suitable for cultivation with $\mathrm{RC}$.

Table 5: Effects of rice bran compost (RC) on the growth of spinach (var. Jiromaru) under greenhouse conditions in the autumn of 2005

\begin{tabular}{|c|c|c|c|}
\hline $\begin{array}{c}\text { RC application } \\
\text { rate } \\
(\% \text { of soil) }\end{array}$ & $\begin{array}{l}\text { Plant } \\
\text { height } \\
(\mathrm{mm})\end{array}$ & $\begin{array}{c}\text { Fresh } \\
\text { weight } \\
\left(\mathrm{g} \mathrm{plant}^{-1}\right)\end{array}$ & $\begin{array}{c}\text { Leaf } \\
\text { chlorophyll } \\
\text { content } \\
\left(\mathrm{mg} 100 \mathrm{~cm}^{-2}\right)\end{array}$ \\
\hline 0 (Control) & $83.0 \mathrm{bc}$ & $1.45 \mathrm{c}$ & $2.87 \mathrm{~b}$ \\
\hline 10 & $161.0 \mathrm{a}$ & $8.55 \mathrm{a}$ & $3.53 \mathrm{a}$ \\
\hline 20 & $98.0 \mathrm{~b}$ & $3.11 \mathrm{~b}$ & $3.49 \mathrm{a}$ \\
\hline 30 & $69.2 \mathrm{c}$ & $0.70 \mathrm{~d}$ & $3.27 \mathrm{ab}$ \\
\hline
\end{tabular}

Values in the column with same letter are not significantly different at $\mathrm{P}<0.05$. All data were collected 30 days after sowing of seed except seed germination. 


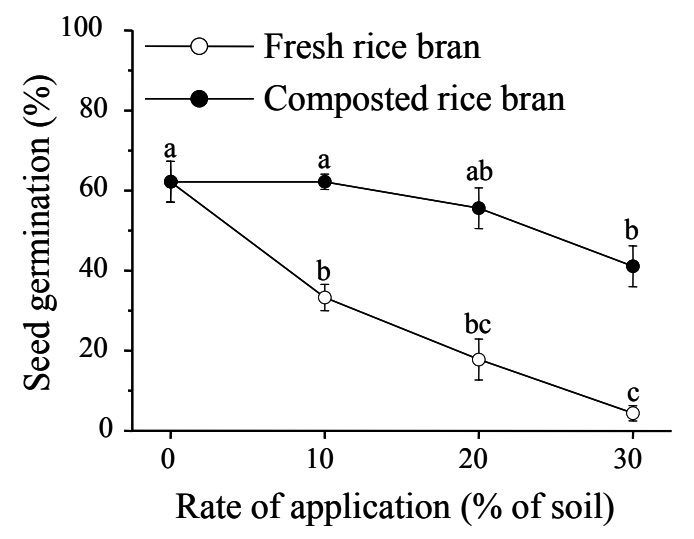

Fig. 3: Effects of fresh and composted rice bran on the seed germination of spinach under greenhouse conditions. Data was collected 10 days after sowing of seeds. Error bars represent \pm SD from 3 replications

\section{ACKNOWLEDGEMENT}

We are thankful to the Ministry of Education, Culture, Sports, Science and Technology, Japan for providing scholarship to M.A.I. Khan. We are also grateful to Ray Kinnane for the English checking of this manuscript.

\section{REFERENCES}

1. Crnko, G.S., W.H. Stall and J.M. White, 1992. Sweet corn weed control evaluations on mineral and organic soils. Proc. Fla. State. Hort. Soc., 105: 326-328.
2. Nelson, L., J. Giles, C. Macllwain and V. Gewin, 2004. Organic FAQs. Nature, 428: 796-798.

3. Rice, E.L., 1984. Allelopathy, Second ed. Academic Press Inc., Orlando, FL., pp: 1-422.

4. Barber, S. and C.B. De Barber, 1980. Rice bran: chemistry and technology. In: Rice: Production and Utilization. (ed B.S. Luh) pp. 790-862. Avi Publishing, Westport.

5. Watanabe, Y., F. Uchiyama and K. Yoshida, 1994. Compositional changes in spinach (Spinacia oleracea L.) grown in the summer and in the fall. J. Jpn. Soc. Hortic. Sci., 53: 434-441.

6. Kuk, Y-I., N.R. Burgos and R.E. Talbert, 2001. Evaluation of rice by-products for weed control. Weed Sci., 49: 141-147.

7. Ozores-Hampton, M.P., 1998. Compost as an alternative weed control method. HortSci., 33: 938940.

8. Tam, N.F.Y. and S. Tiquia, 1994. Assessing toxicity of spent pig-littre using a seed germination technique. Resour. Conserv. Recycle, 11: 261-274.

9. Nagaoka, T., K. Umezu, K. Kouno, S. Yoshida, Y. Ishiguro and T. Ando, 1996. Selective inhibitors of germination of legume seeds in activated sludge compost. Plant Growth Regul., 20: 295-302.

10. Kato-Noguchi, H., 2000. Assessment of the allelopathic potential of extracts of Evolvulus alsinoides. Weed Res., 40: 343-350.

11. Hu, Y. and A.V. Barker, 2004. Evaluation of composts and their combinations with other materials on tomato growth. Communications Soil Sci. Plant Analysis, 35: 2789-2807. 